\title{
Proceeding
}

Supplementary Issue: Autumn Conferences of Sports Science. Costa Blanca Sports Science Events, 18-19 December 2020. Alicante, Spain.

\section{The effective use of heritage sites of the major sporting events in Russia}

\author{
OLEG ALEKSANDROVICH BUNAKOV1 1 , DMITRY VLADIMIROVICH RODNYANSKY1, BORIS \\ MOJSHEVICH EIDELMAN1', ELENA VALERIEVNA GRIGORIEVA ${ }^{1}$, TIMOFEY VASILYEVICH \\ BASHLYKOV2 \\ ${ }^{1}$ Institute of Management, Economics and Finance, Kazan Federal University, Russian Federation \\ ${ }^{2}$ Department of Economics, Management and Marketing, Kazan Federal University, Russian Federation
}

\begin{abstract}
This article dwells on the positive and negative experience of using facilities remaining after the major sporting events in the country. The authors analyse the use of stadiums built for the FIFA World Cup, as well as the facilities of Kazan involved during the Universiade 2013. The research resulted in the conclusion about the necessity as far back at the designing stage to study both the relevancy of the sporting venue during the event and its potential usage afterwards. The authors make a point that there is a positive emotional effect, which is revealed in the growth of tourism, and increasing the attractiveness of the territory for local residents. The results obtained can be useful for cities and countries that have yet to host major sports events.

Keywords: Heritage sites; Effective use; Sporting events.

\section{Cite this article as:}

Bunakov, O.A., Rodnyansky, D.V., Eidelman, B.M., Grigorieva, E.V., \& Bashlykov, T.V. (2021). The effective use of heritage sites of the major sporting events in Russia. Journal of Human Sport and Exercise, 16(2proc), S427-S433. doi:https://doi.org/10.14198/ihse.2021.16.Proc2.28
\end{abstract}

Corresponding author. Institute of Management, Economics and Finance, Kazan Federal University, Russian Federation. https://orcid.org/0000-0003-3018-523X

E-mail: o.publication34@mail.ru

Abstract submitted to: Autumn Conferences of Sports Science. Costa Blanca Sports Science Events, 18-19 December 2020. Alicante, Spain.

JOURNAL OF HUMAN SPORT \& EXERCISE ISSN 1988-5202

(c) Faculty of Education. University of Alicante

doi:10.14198/jhse.2021.16.Proc2.28 


\section{INTRODUCTION}

In the modern world, a large number of sporting events of various scope and levels take place annually. One should especially distinguish the World championships and, of course, the Summer and Winter Olympic Games and Universiades taking place for a long time (from 2 weeks or more) and requiring proper build-up of all the necessary infrastructure. Moreover, the interest in such kind of events is also strong because they are usually held every 2-4 years and become a festive occasion for millions of guests and fans.

After the World War II practically all of the most significant sports events were held in the country's capitals or in the largest cities of developed countries, e.g., London hosted the Olympic Games twice (in 1944 and 1948). It is due to the fact that the requisite conditions are created in the capitals initially and a point refinement is just required.

\section{METHOD}

However, at the beginning of the 21st century the situation began to change. In 2010, for the first time in history, the World Cup was held in Africa (South Africa) and the Summer Olympic Games of 2016 in South America (Brazil). The experience of parallel using several cities and even countries for one event began to be actively applied. There are several reasons:

1) it is much easier to assure safety for athletes and spectators due to dispersal.

2) it is more evenly sharing of load upon hotels, transport system, catering facilities, places of leisure and entertainment, sightseeing.

3) tourists are interested in visiting several new places at once, etc.

The preparation for global events usually takes several years and requires significant financial contributions from the state and private investors. The main expectancy of the facilitators is to make the maximum profit directly at the time of the event, when all the constructed facilities are exploited to the utmost (http://www.olympdep.ru). However, immediately after the end of the competition and tourists' departure, some facilities quickly become unwanted for the local population and authorities. As a result, the facilities and complexes constructed just yesterday begin to ruin and make losses instead of bringing profit.

The article is devoted to the positive and negative experience of Russian cities in using heritage sites of major sporting events.

\section{RESULTS}

It was Kazan (Russia), May 31, 2008 that received the right to host the 2013 Summer Universiade. In fact, it was the starting point of the new life of a fairly old city founded in 1005. Over the 5 years of event preparation, a new Ak Bars Arena stadium (Kazan Arena until 2019; Hesam \& rad, 2020) with a seating capacity of 45,000 people was built. In addition, more than 30 sites for various sports were constructed from scratch. A new residential area has appeared - the Universiade Village where athletes and members of official delegations lived during the competition. Moreover, there was the construction of a modern medical centre, a new terminal at the airport, 11 transport junctions (they allow Kazan and up to now, 2020, to avoid serious traffic jams practically), 36 pedestrian crossings, 3 new metro stations.

According to official estimates, the costs of this event in Kazan amounted to about 230 billion rubles and about 40 billion rubles were spent on sporting facilities themselves. 
In the end, by the beginning of the Universiade games, everything was ready and the event itself was held at the highest level due to the responses of athletes and guests of the city. Following the official data of the Universiade Directorate, the execution of this event brought an economic effect of 10.8 billion rubles. The city was visited by more than 100 thousand tourists. It stands to reason, it did not cover all the costs, but it allowed Kazan to reduce the costs of the next major sporting event (the 2015 World Aquatics Championship) significantly. The city did not have to build new facilities, and the facilitators' purpose was only restricted to the proper logistics and the use of existing infrastructure.

By July 2015, the newly built Kazan Arena stadium was re-equipped with 2 additional pools, and the largest swimming event in the world was successfully held. More than 170 thousand tourists visited the city and again the guest comments were the best and the most positive.

Kazan was along with Moscow and St. Petersburg when choosing the cities where the football matches of the FIFA Confederation Cup 2017 and the World Cup 2018 were to take place, and Kazan was seemed an indisputable candidate. The World Cup provided the city with a huge number of tourists $(300,000)$ and brought substantial income of 11.2 billion rubles. Nevertheless, it should be noted that in this case, the expenditure part was already significantly reduced, and the construction of any new structures was not required. As well as the media coverage of these sporting events had a powerful PR effect in attracting attention to Kazan as a tourist destination after the events (Bunakov et al., 2018; Gabdrakhmanov et al., 2014; Eidelman et al., 2019). This is especially evident from the following table (see Figure 1).

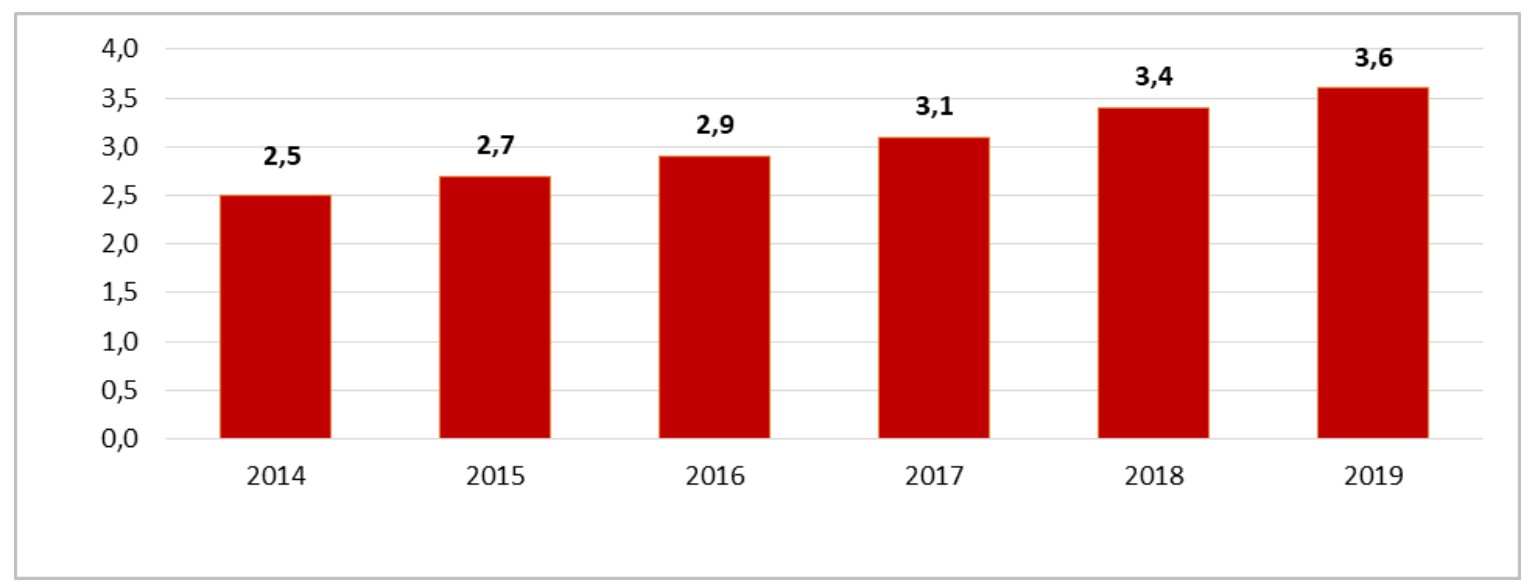

Source: according to the State Committee for Tourism of the Republic of Tatarstan (http://tourism.tatarstan.ru).

Figure 1. Number of tourists visited Kazan in 2014-2019.

In 2019 , Kazan was visited by $7 \%$ of tourists more than in the year of the World Cup and the number of foreign guests did not decrease practically (about 335,000).

The entire infrastructure, and especially the facilities built for the 2013 Universiade, made up the so-called heritage which must be used for the benefit of the residents of the city, as well as for extra income to the budget, or competitive advantages. 28 constructed houses of the Universiade Village were handed on to the Kazan Federal University (KFU), as well as the Volga Academy of Physical Culture, Sports and Tourism (VAPCST). Thus, KFU received the largest modern campus equipped with everything in accordance to standards and requirements. It has become a key strength of the university when admitting applicants from other cities of Russia and countries of the world. 
Moreover, both KFU and VAPCST also got several sports facilities for their possession. At the same time, it should be mentioned that the issue of the received facilities maintaining was also passed under the control of universities thereby relieving the city from unnecessary costs.

Some of the facilities stood at the balance of the city providing the opportunities for citizens to do sports often including completely free of charge. According to statistics, by 2019 in Kazan, more than $30 \%$ of residents go in for sports on an ongoing basis.

Since its opening in 2013, the main site of the Universiade's heritage, the Ak Bars Arena stadium, has been involved in a large number of projects and has received few football matches to this day. This facility can be considered successful as it closed the 2019 fiscal year with a profit and as a whole became a platform for holding city events.

It should be emphasized that when designing large stadiums, it is desirable to place them in the central part of the city contributing to:

1) High transport and pedestrian accessibility.

2) The possibility of easier attracting businesses (catering, entertainment).

3) The inclusion of the site in the city sightseeing programs, etc.

In order to hold the World Cup in 2018, 12 stadiums in 11 cities were involved. Only 3 stadiums from this number were initially ready to hold matches. That is why significant financial and human resources were required respectively in order to build 9 stadiums from scratch in a short period.

The most problem-plagued in terms of construction were the facilities in Kaliningrad and Samara opened almost at the final lap of the World Cup preparation. The stadium in Kaliningrad was built on a swampy island and initially looked like a very dubious project. A city with a population of less than 700,000 people did not need such a site (the seating capacity of the stadium was 35,000 people) and it was clear that after the event there would be problems loading it. The construction of the stadium cost 17.8 billion rubles and about 300 million rubles are needed for its maintenance annually.

In 2019 the stadium was passed under the control of the city balance. The main source of income is renting out for football matches, but in Russia, on average, football attracts about 15,000 spectators; many sport teams prefer to rent smaller and cheaper stadiums. For a football match, the stadium is usually rented for 4 days, and for $15-17$ home games, only about 65 days are involved. Therefore, the main problem is the exploitation of the facility in free time from matches.

Currently, the Kaliningrad Stadium, in addition to matches of the World Cup, has hosted only a few international rugby matches and has been idle for almost 2 years. In many European countries' concerts, business events and even weddings are held at such kind of facilities. Probably, it also was possible in Kaliningrad with proper facility planning and designing.

Once again, one can apply to the Ak Bars Arena in Kazan where the stadium has a museum, conference venues, a fitness centre and even a hotel. The stadium itself is easily transformed for almost any need. It is determined by the expensive plan of the stadium at the design stage but significant opportunities after putting into operation. 
A good perspective for all-year exploitation of the stadium can be the realization of a beautiful and multifunctional park in the surrounding area. Its visitors will use the facility's infrastructure (primarily catering facilities) and thereby attract businesses to the facility.

One should take note of the Samara Arena stadium. The construction of this facility cost almost 19 billion rubles and was completed immediately before the World Cup. The stadium was opened on April 28, 2018. It was built in the form of a flying saucer. As envisioned by architects it should be a reminder that the city of Samara is one of the space industries centres in Russia.

The stadium seating capacity was 44,000 people which is a normal indicator for a city like Samara. However, in September 2018 (only 2 months after the end of the World Cup matches), the site faced with financial and technical problems continuing up to the present.

In general, speaking about the stadiums of the 2018 World Cup it can be said that only 4 facilities have no financial problems and difficulties with their exploitation: 2 stadiums in Moscow, Ak Bars Arena in Kazan, Fisht in Sochi, Gazprom Arena in St. Petersburg. The rest ones became a heavy burden for local authorities due to various circumstances but primarily due to design flaw and ineffectual location (Tsapfak et al., 2019; Lebedeva, 2019).

The total construction cost of 7 arenas amounted to 149 billion rubles and it was initially clear that a program for the facilities exploitation of after the World Cup was needed. In the autumn of 2018, the Russian government approved the "World Cup Heritage Concept", which supposes assistance of 7 stadiums to become self-sustaining by 2023. The program did not include Ak Bars Arena, Fisht Stadium, St. Petersburg and Luzhniki Stadium, as they had received contribution earlier, as well as Otkrytiye Arena owned by the structures of Spartak football club owner Leonid Fedun.

Table 1. Distribution of funds among the constructed stadiums under the program "Heritage of the World Cup".

\begin{tabular}{lccc}
\hline Stadium & $\begin{array}{c}\text { Adapting to heritage } \\
\text { mode (mln. rub) }\end{array}$ & $\begin{array}{l}\text { Federal budget grants } \\
\text { for exploitation in } \\
\mathbf{2 0 1 9 - 2 0 2 3} \text { (mln. rub) }\end{array}$ & $\begin{array}{l}\text { The total financing } \\
\text { (mln. rub) }\end{array}$ \\
\hline Volgograd Arena & 70.8 & 1643.1 & 1713.9 \\
Yekaterinburg Arena & 570.8 & 1824.9 & 2395.7 \\
Samara Arena & 70.8 & 1752.4 & 1823.2 \\
Mordovia Arena & 70.8 & 1488.6 & 1559.4 \\
Nizhny Novgorod & 70.8 & 1706 & 1776.8 \\
Rostov & 70.8 & 1787.2 & 1858 \\
Kaliningrad Arena & 70.8 & 1756.2 & 1827 \\
\hline Source: RBC official & website. & Access Mode: & https://www.rbc.ru/society/21/07/2018/5b51f8c79a79470df8d82c46 \\
(https:/www.rbc.ru) & & &
\end{tabular}

The assistance proposes 2 expense items (see Table 1). The amounts allocated seem significant, but they cannot fully cover the costs. So, the concept also offers a list of options for other commercial use of stadiums, including concerts, festivals, exhibitions, mass viewing of sports competitions on the large screen, city holidays and amateur competitions. It is also envisaged the possibility of renting the premises of stadiums, but only for certain types of activities, in order to avoid, for example, the appearance of markets (as it happened in the 90s at the Luzhniki stadium). The control over the intended use of the facilities passed under 
the local authorities having taken the stadiums to their balance since 2019 (Ramazanov, 2018; World Cup 2018; de Lima, 2018).

Volgograd Arena, Mordovia Arena and Kaliningrad are considered the most dysfunctional facilities primarily due to the small number of population and low living standards.

\section{SUMMARY}

After the World Cup in Kazan, in summing up, it turned out that a huge amount of beer was drunk during the matches in the stadiums and fan zones which generally did not affect the safety of the events. In this regard, the President of the Republic of Tatarstan R. N. Minnikhanov advanced the initiative of possibility to sell beer at stadiums, which would increase their profitability. There is also an initiative to get the FAN ID as a necessary document for access to the arenas, since the experiment of their use during the World Championship was recognized as successful.

\section{DISCUSSION AND CONCLUSION}

So, one can draw the following conclusions:

1) In the modern world having the competent strategic planning makes it possible prepare all the necessary infrastructure for the largest sporting events in such a way that after the end of the event it brings benefits to the city, region, country.

2) A lot of factors should be taken into account, such as: population size, geographical position, living standards of the local population, the presence of popular teams, the demand for the city in large venues when choosing venues for events.

3) A major sporting event gives impetus to the development of the tourism industry with an effect lasting at least 1 year.

4) The heritage of sporting events can contribute to significant social changes in the territory making it more attractive both for tourists and for permanent residence.

It is evident that, in any single case, the influence of major sporting events produced a different effect. In Russia, along with successful examples, there are the projects which hit the budget most seriously and did not bring the expected benefits. Then again, one can still take up the position that in addition to the economic component, there is also an emotional component which is extremely difficult to estimate and monetize. Thus, it will be the research question of our future studies.

\section{ACKNOWLEDGEMENTS}

The work is performed according to the Russian Government Program of Competitive Growth of Kazan Federal University.

\section{REFERENCES}

Bunakov, O.A., Zaitseva, N.A, Larionova, A.A, Zhukov, V.A., Morozova, M.A., \& Dmitrieva, N.V. (2018). The use of the soft power concept in the modern Russian tourism industry. Espacios, 39(22), Art. № 2.

de Lima, R. S. (2018). Violence and public safety as a democratic simulacrum in Brazil. International Journal of Criminology and Sociology, 7, 159-172. https://doi.org/10.6000/1929-4409.2018.07.11 
Eidelman, B.M., Bunakov, O.A., \& Fakhrutdinova, L.R. (2019). The main directions of supply chain management development of territorial branding in Russia in modern conditions. International Journal of Supply Chain Management., 8(4).

Gabdrakhmanov, N.K., Rubtzov, V.A., Shabalina, S.A., Rozhko, M.V., Kucheryavenko, D.Z. (2014). The role of territorial organization of cities in the touristic attraction of the region on the example of the Republic of Tatarstan. Life Science Journal, 11(12), 451-455.

Hesami, M., \& Rad, S. S. (2020). The relationship between knowledge management and employee education knowledge in Power Distribution Company of Golestan province. Journal of management and accounting studies, 8(2).

Lebedeva, T.E. (2019). A study of the prospects for using the heritage of the World Cup 2018 in Nizhny Novgorod. Innovative Economics: prospects for development and improvement, 4(38), 169-174.

Official RBC website. [Electronic resource] I Access mode: https://www.rbc.ru/society/21/07/2018/5b51f8c79a79470df8d82c46

Ramazanov, Sh.M. (2018). Management of the elements of football infrastructure after the World Cup 2018: foreign experience and Russian prospects. Management, 6(2), 32-38. https://doi.org/10.26425/2309-3633-2018-2-32-38

Tsapfak, K., Lebedeva, T.E., \& Lazutina, A.L. (2019). Marketing research on the relevance of heritage sites of the 2018 World Cup in Nizhny Novgorod. Actual problems of the modern economy, 4, 12041207.

Website of the Department of Olympic Heritage of the Krasnodar Territory. [Electronic resource]. Access mode: http://www.olympdep.rul

Website of the State Committee of the Republic of Tatarstan on Tourism. [Electronic resource]. Access mode: http://tourism.tatarstan.ru/rus/documents.htm?pub id=2245182

World Cup 2018. A powerful impetus for the development of tourism [Electronic resource].

\section{(@) $\odot \Theta \Theta$}

This work is licensed under a Attribution-NonCommercial-NoDerivatives 4.0 International (CC BY-NC-ND 4.0). 